\section{PEER-REVIEWED ARTICLE}

Food Protection Trends, Vol 41, No. 1, p. 46-55 Copyright 2021 , International Association for Food Protection 2900 100th Street, Suite 309, Des Moines, IA 50322-3855
Bingzhuo C. Zhao, Eleanor J. Hanson and Barbara H. Ingham*

Dept. of Food Science, 1605 Linden Drive, University of Wisconsin-Madison, Madison, WI 53706, USA

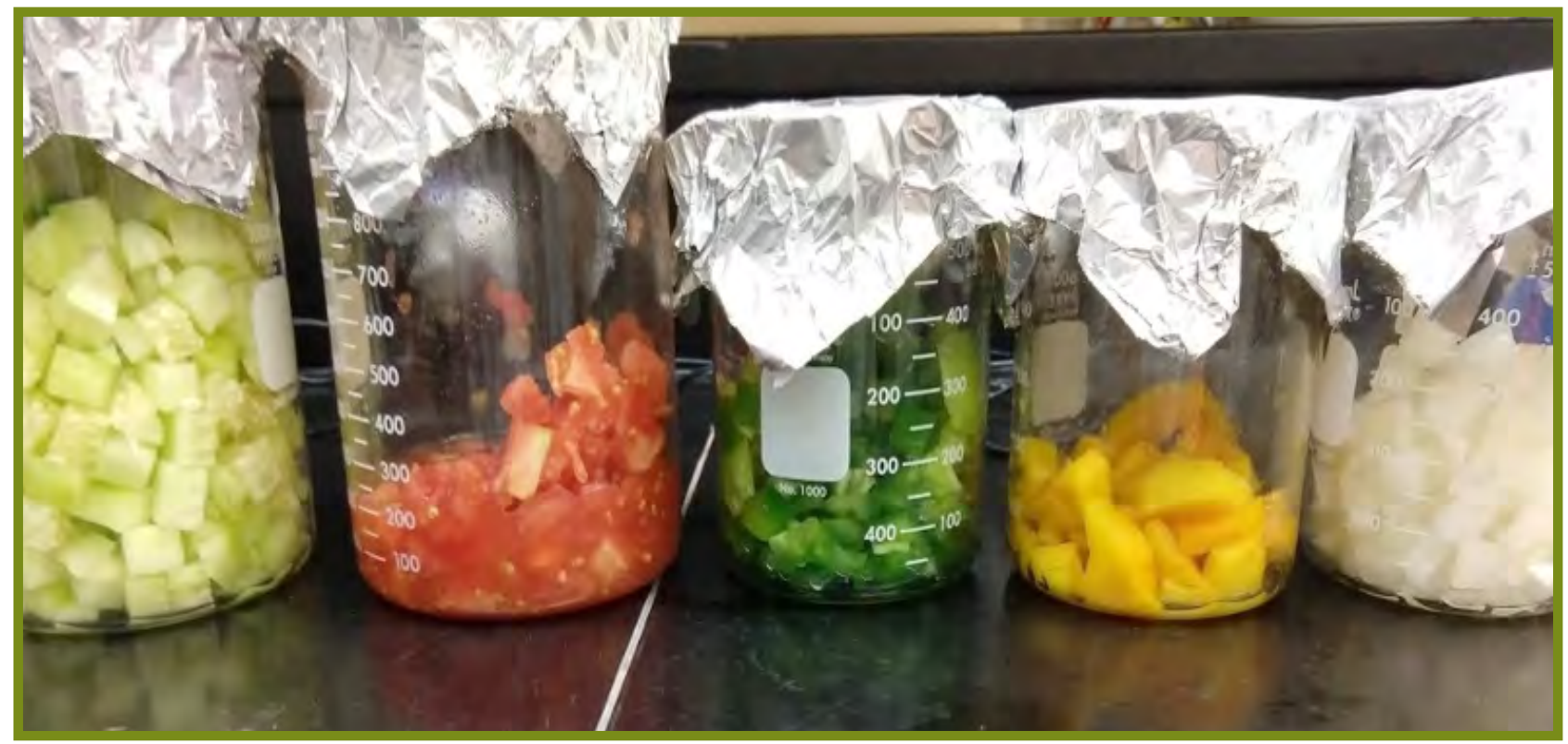

\title{
Holding Fresh-Cut Produce under Refrigeration May Not Prevent Pathogen Growth: Implications for Time-Temperature Control to Reduce Risk
}

\section{ABSTRACT}

The U.S. Food and Drug Administration Food Code suggests that holding fresh-cut produce at $\leq 5^{\circ} \mathrm{C}$ will limit growth of pathogenic microorganisms. Here, we determined whether cucumber, onion, pepper, mango, and tomato supported growth of Listeria monocytogenes (LM), Shiga toxin-producing Escherichia coli (STEC), and Salmonella enterica (SALM) at 5, 10, and $22^{\circ} \mathrm{C}$. Produce was surface-pasteurized, diced, inoculated with single-pathogen cocktails, and incubated. Survivors were then enumerated with change in population ( $\Delta$-log CFU per gram) determined over time. Mango did not support pathogen growth at 5 or $10^{\circ} \mathrm{C}$, but SALM and STEC exhibited significant $(P<0.05)$ growth on mango at $22^{\circ} \mathrm{C}$ (2.85 and $1.41 \Delta$-log CFU/g, respectively). At $5^{\circ} \mathrm{C}$, significant $(P<0.05)$ growth was seen on cucumber inoculated with SALM and LM; onion and pepper inoculated with LM; and tomato inoculated with STEC. At $10^{\circ} \mathrm{C}$, freshcut cucumber, onion, and pepper supported significant $(P<0.05)$ increases in SALM, STEC, and LM, along with SALM on tomato; $\Delta$-log ranged from 3.37 (onion, LM) to
5.40 CFU/g (pepper, SALM). Growth of pathogens was not significantly different $(P<0.05)$ at 10 and $22^{\circ} \mathrm{C}$ for SALM or STEC inoculated onto onion, pepper, cucumber, or tomato. Results suggest that holding fresh-cut produce at or near refrigeration temperatures $\left(5\right.$ or $10^{\circ} \mathrm{C}$ ) may not control risk of pathogen growth.

\section{INTRODUCTION}

As Americans look to fresh fruits and vegetables as healthy diet choices $(16,33)$, produce consumption has increased. However, the lack of a lethality step in the manufacture of fresh-cut produce and a global produce distribution network have contributed to increased foodborne illness outbreaks linked to fresh produce (3). Listeria monocytogenes (LM), Salmonella enterica (SALM), and Shiga toxin-producing Escherichia coli (STEC) have been isolated from raw produce $(21,29,37-39)$ and have been linked to produce-related outbreaks $(1,8,24,35,46-47)$. In 2015, Salmonella Poona was identified in an outbreak associated with cucumber that resulted in $>900$ cases of illness, 204 hospitalizations, and six deaths $(4,5)$. In 2011, an outbreak of listeriosis traced to 
whole cantaloupe caused 146 illnesses in 28 U.S. states and led to 32 deaths and one miscarriage (30).

The U.S. Food and Drug Administration (FDA) Food Code aims to ensure safe food handling and preparation in retail food establishments across the United States. The Food Code identifies certain foods as time-temperature control for safety (TCS) foods; these foods require timetemperature control to limit growth or toxin formation by pathogenic microorganisms (43). TCS foods specifically cited in the definition are raw seed sprouts, cut melons, cut leafy greens, and cut tomatoes or mixtures of cut tomatoes that are not modified in a way so that they are unable to support pathogenic microorganism growth or toxin formation (43). Foods not specifically cited are designated non-TCS on the basis of $\mathrm{pH}$ and water activity (Table 1 ). Except during preparation or similar steps, or under certain holding conditions, TCS foods must be maintained at $\leq 5^{\circ} \mathrm{C}$ (43). Most fruit have a natural or normal $\mathrm{pH}<4.2$ and would be considered non-TCS. Exceptions are cut melon and cut tomato that are specifically cited in the definition of TCS foods. Vegetables tend to have $\mathrm{pH}>4.2$ and $\mathrm{a}_{\mathrm{w}}>0.92$ and would require a product assessment to determine the need for TCS (Table 1).

The goal of this project was to determine the impact of holding temperature on the survival of SALM, STEC, and LM on fresh-cut cucumber, onion, pepper, and mango. Produce items were held at or near refrigeration temperature $\left(5\right.$ or $10^{\circ} \mathrm{C}$ ) or at room temperature $\left(22^{\circ} \mathrm{C}\right)$. Cut tomato, listed as a TCS food in the Food Code, were included as a positive control. We aimed to determine whether holding under refrigeration would limit pathogen growth on a variety of produce as expected and to establish the risk that may be posed to public health by the presence of pathogens on freshcut produce held under typical retail handling conditions.

\section{MATERIALS AND METHODS \\ Produce preparation}

Whole produce, procured from local grocery stores

(Madison, WI) included tomato, cucumber, onion, green pepper, and mango. Produce items were held at $4 \pm 2{ }^{\circ} \mathrm{C}$ before use in experiments. Whole items were surface pasteurized by dipping in boiling water $\left(100^{\circ} \mathrm{C}\right)$ for $30 \mathrm{~s}$ and then aseptically peeled (tomato, cucumber, onion, and mango) and chopped into 1-cm cubes by using an alcoholsanitized vegetable chopper. Chopped flesh from each produce type was collected in a sterile beaker, mixed, and dispensed into sterile Whirl-Pak filter bags $(15.2$ by $22.9 \mathrm{~cm}$; Nasco, Ft. Atkinson, WI) at $25 \mathrm{~g}$ per bag. The $\mathrm{pH}$ of each produce item was measured at the beginning of each trial by using a calibrated meter (Accumet AB150, Fisher Scientific, Itasca, IL). Water activity was measured at the initiation of the study, once per produce item, by using a calibrated meter (Aqualab, Meter Group, Pullman, WA).

\section{Pathogen selection and maintenance}

Pathogen strains originally isolated from produce or produce-related outbreaks were used in this study (Table 2). Strain identity was confirmed by evaluating Gram reaction, cell morphology, and biochemical profile (API20E and API Listeria, bioMérieux, Durham, NC). Stock cultures for each strain were maintained frozen $\left(-20^{\circ} \mathrm{C}\right)$ in tryptic soy broth (TSB; Difco, BD, Sparks, MD) containing 50\% glycerol (v/v) (Fisher Scientific).

Working cultures were prepared by streaking for isolation from frozen stock cultures onto selective media. STEC and SALM strains were streaked onto Levine's eosin methylene blue agar (Difco, BD) modified with the addition of $10 \mathrm{~g} / \mathrm{L}$ D-sorbitol (Fisher Scientific) and $5 \mathrm{~g} / \mathrm{L} \mathrm{NaCl}$ (MEMB; Fisher Scientific); LM strains were streaked onto Listeria selective agar (LSA; Oxoid Ltd., Basingstoke, England) with added Listeria selective supplement (Oxoid Ltd.). Working culture plates were incubated at $35^{\circ} \mathrm{C}$ for $24 \pm 2 \mathrm{~h}$ and then stored at $4^{\circ} \mathrm{C}$ and refreshed monthly.

\section{Inoculum preparation}

Each single-pathogen inoculum cocktail was prepared by picking a single isolated colony from a working culture plate for each strain into a separate tube containing $9 \mathrm{~mL}$ of TSB

TABLE 1. Interaction of pH and water activity for control of vegetative cells and spores in food not heat treated or heat treated, but not packaged (43)

\begin{tabular}{l|c|c|c|c}
\hline $\mathrm{a}_{\mathrm{w}}$ value & $\mathrm{pH}<4.2$ & $\mathrm{pH} 4.2-4.6$ & $\mathrm{pH}>4.6-5.0$ & $\mathrm{pH}>5.0$ \\
\hline$<0.88$ & Non-TCS food $^{a}$ & Non-TCS food & Non-TCS food & Non-TCS food $^{\text {Pon-TCS food }}$ \\
\hline $0.88-0.90$ & Non-TCS food & Non-TCS food & Non-TA & PA $^{b}$ \\
\hline $0.90-0.92$ & Non-TCS food & Non-TCS food & PA & PA \\
\hline 0.92 & Non-TCS food & PA & PA & PA \\
\hline
\end{tabular}

${ }^{a}$ TCS food means time-temperature control for safety of food.

${ }^{b} \mathrm{PA}$, product assessment required. 


\section{TABLE 2. Pathogen strains used in this study}

\begin{tabular}{|c|c|c|c|c|}
\hline Species & Serotype & Strain or designation & Origin & Source $^{a}$ \\
\hline \multirow{10}{*}{ Escherichia coli } & O111:H- & RC-313-007 & & WSLH \\
\hline & O145 & $99-33-11$ & & WSLH \\
\hline & $\mathrm{O} 103: \mathrm{H} 2$ & RC-289-003 & & WSLH \\
\hline & O104:H4 & RC-401-014 & Sprouts-linked outbreak, Germany & WSLH \\
\hline & O26:H11 & RC-431-068 & Sprouts-linked outbreak & WSLH \\
\hline & O157:H7 & E0018 & Calf feces & UGA \\
\hline & O157:H7 & C7929 & Apple cider & UGA \\
\hline & O157:H7 & F4546 & Sprouts & UGA \\
\hline & O157:H7 & H1730 & Lettuce & UGA \\
\hline & $\mathrm{O} 157: \mathrm{H} 7$ & SEA 13B88 & Apple cider & UGA \\
\hline \multirow{9}{*}{ Salmonella enterica } & Agona & & Alfalfa sprouts & UGA \\
\hline & Baildon & & Patient isolate (tomato-linked outbreak) & UGA \\
\hline & Gaminara & & Orange juice & UGA \\
\hline & Michigan & & Cantaloupe & UGA \\
\hline & Montevideo & & Patient isolate (tomato-linked outbreak) & UGA \\
\hline & & $177114 \mathrm{~A}$ & Green peas (outbreak strain) & WSLH \\
\hline & & $177114 \mathrm{~B}$ & Green peas (outbreak strain) & WSLH \\
\hline & & 752072 & Green peas (outbreak strain) & WSLH \\
\hline & & 722078 & Green peas (outbreak strain) & WSLH \\
\hline \multirow{5}{*}{ Listeria monocytogenes } & $1 / 2 \mathrm{a}$ & $\mathrm{H} 0222$ & $\begin{array}{l}\text { Potato } \\
\end{array}$ & UGA \\
\hline & $4 \mathrm{~b}$ & G1091 & Patient isolate (coleslaw-linked outbreak) & UGA \\
\hline & $1 / 2 \mathrm{a}$ & F8369 & Corn & UGA \\
\hline & $1 / 2 b$ & F8255 & Peach and plum & UGA \\
\hline & $4 \mathrm{~b}$ & F8027 & Celery & UGA \\
\hline
\end{tabular}

"WSLH, Wisconsin State Laboratory of Hygiene; UGA, University of Georgia, courtesy of L. Beuchat.

plus $1 \%$ glucose. Cultures were incubated for $24 \pm 2 \mathrm{~h}$ at $35^{\circ} \mathrm{C}$. After incubation, $1 \mathrm{~mL}$ from each strain was combined in a single $15-\mathrm{mL}$ conical centrifuge tube to create three single-pathogen cocktails.

Tubes containing multiple strains were centrifuged (Marathon 21K, Fisher Scientific) at 8,000 rpm for $7 \mathrm{~min}$. The supernatant from each tube was discarded, and each pellet was resuspended in Butterfield's phosphate diluent (BPD; $3 \mathrm{M}$, Minneapolis, $\mathrm{MN}$ ) to create a single-pathogen inoculum cocktail of $\sim 10^{9} \mathrm{CFU} / \mathrm{mL}$. Cocktails were serially diluted in $\mathrm{BPD}$, as appropriate, to achieve an inoculum concentration of $\sim 10^{4} \mathrm{CFU}$ pathogen per gram of fresh produce.

\section{Produce inoculation and incubation}

For a given trial, bags of cut retail produce $(25 \mathrm{~g})$, prepared as described above, were individually inoculated with $250 \mu \mathrm{L}$ of a single-pathogen cocktail of SALM, STEC, or LM to yield an average starting inoculum concentration of $4.78,4.77$, or 4.15 CFU/g, respectively, across three complete trials. Three bags remained uninoculated and were used for enumeration of native microflora at time zero. Once inoculated, bags were gently massaged by hand for $30 \mathrm{~s}$ to disperse the inoculum and then placed into an incubator set at $5 \pm 1,10 \pm 1$, or $22 \pm 1^{\circ} \mathrm{C}$.

\section{Bacterial enumeration}

Surviving pathogens were enumerated from one bag for each pathogen-produce combination (three bags per produce type) at select time-temperature combinations as follows: at $5^{\circ} \mathrm{C}$, enumeration at $0,24,48,72,96,120$, and $168 \mathrm{~h}$; at $10^{\circ} \mathrm{C}$, enumeration at $0,12,24,48,72$, and $96 \mathrm{~h}$; and at $22^{\circ} \mathrm{C}$, enumeration at $0,4,8,18,24$, and $32 \mathrm{~h}$. For an inoculated bag, at each sampling time, $99 \mathrm{~mL}$ of BPD was added, and the 
bags were stomached at $260 \mathrm{rpm}$ for $2 \mathrm{~min}$. An aliquot of the resulting homogenate was serially diluted in BPD and spread plated for enumeration. Total microbiota were enumerated on nonselective media: tryptic soy agar $(0.1 \mathrm{~mL}$ aliquots; Difco, BD) and TPC Petrifilm (1 mL; 3M). Pathogens were enumerated on selective media (0.1 mL): MEMB for SALM and STEC and LSA for LM. Plates were incubated for 24 to $48 \mathrm{~h}$ at $35 \pm 1^{\circ} \mathrm{C}$, and typical colonies were then counted. Surviving native microbiota levels were determined by subtraction. Three independent trials were conducted for each produce-pathogen-temperature combination.

\section{Statistical analysis}

Pathogen levels (log CFU per gram) were plotted over time for each produce item at a given temperature. The Combase DMFit model using the integrated model of Baranyi and Roberts (https://www.combase.cc/index. $\mathrm{php} / \mathrm{en} /)$ was used to generate rates of growth ( $\mu$; log CFU per gram per hour). $\Delta$-log CFU per gram was calculated by subtraction: time final - time $_{0}$. Bacterial level (log CFU per gram) at each sampling time for replicate trials $(n=3)$ was compared using the Sen-Adichie test for parallelism calculated in Mstat version 6.4.2 (https://mcardle.wisc.edu/ mstat/). Growth rates and $\Delta$-log CFU per gram values for a given produce-pathogen combination across temperatures and $\Delta$-log CFU per gram values across pathogens for a given produce-temperature combination were compared using one-way analysis of variance (ANOVA) followed by unpaired $t$-test by using Prism version 7.00 for Windows (GraphPad Software, La Jolla, CA; www.graphpad.com). Differences are considered significant at $P<0.05$.

\section{RESULTS AND DISCUSSION}

Produce items chosen for this study were selected based on their association with foodborne illness outbreaks or ready availability in fresh-cut form in retail food establishments. Multiple illness outbreaks in the United States and elsewhere have been linked to onion (48), pepper $(25,32)$, mango ( 9 , $23,40)$, cucumber $(4,5,14)$, and tomato $(10,11)$.

Excluding mango, which did not support pathogen growth overall, the rate of growth for pathogen-produce combinations across temperatures followed the trend $5^{\circ} \mathrm{C}$ $<10^{\circ} \mathrm{C}<22^{\circ} \mathrm{C}$ (Table 3), and, except for tomato inoculated with $\mathrm{LM}$, the rate of growth at $5^{\circ} \mathrm{C}<$ rate of growth at $22^{\circ} \mathrm{C}$ $(P<0.05$; Table 3). Similarly, Fang et al. (20) modeled the growth of different serotypes of LM and background microbiota on fresh-cut cantaloupe and found that temperature was the only factor that significantly affected specific growth rate.

Product $\mathrm{pH}$ strongly influences the survival and growth of pathogens on fresh and fresh-cut produce. The average initial $\mathrm{pH}$ of retail produce items ranged from 3.58 for mango to 5.67 for cucumbers, and water activity ranged from 0.993 to 0.998 (Table 4). The combination of a short thermal pasteurization and peeling, where used, reduced native microbiota to 1 to $3 \log \mathrm{CFU} / \mathrm{g}$ (Table 4) with no discernible affect on product quality (data not shown).

The FDA Food Code outlines characteristics of $\mathrm{pH}$ and water activity that define whether a product requires TCS (Table 1) and directs that TCS foods be held at $\leq 5^{\circ} \mathrm{C}$ to "... limit pathogenic microorganism growth or toxin formation" (43). Of the produce items included in this study, only mango ( $\mathrm{pH} 3.58$ ) would be considered non-TCS, i.e., not requiring time and temperature control.

Mango did not support growth of any pathogens on holding at $5^{\circ} \mathrm{C}$, as expected, nor at $10^{\circ} \mathrm{C}$ (Table 3 ). However, placing fresh-cut mango at $22^{\circ} \mathrm{C}$ and holding for up to 32 $\mathrm{h}$ allowed significant growth of SALM and STEC $(\Delta-\log$ $\mathrm{CFU} / \mathrm{g}$ of 2.85 and 1.41, respectively). LM inoculated on fresh-cut mango did not grow over $32 \mathrm{~h}$ at $22^{\circ} \mathrm{C}$ (Table 3). Strawn and Danyluk (41) investigated the fate of Escherichia coli O157:H7 and Salmonella spp. on fresh-cut mango inoculated and held at 4,12 , and $23^{\circ} \mathrm{C}$. Unlike our results, they observed growth of SALM inoculated on mango at $12^{\circ} \mathrm{C}$, and pathogen populations increased over the first day on incubation at $4^{\circ} \mathrm{C}$. Similar to our study, however, E. coli O157:H7 inoculated onto mango slices held at 4 or $12^{\circ} \mathrm{C}$ were virtually unchanged (41). At $23^{\circ} \mathrm{C}$, they observed an increase in SALM populations on mango slices of up to $3 \mathrm{log}$ $\mathrm{CFU} / \mathrm{g}$ within the first $24 \mathrm{~h}$, similar to the $2.85 \mathrm{log} \mathrm{CFU} / \mathrm{g}$ we observed in SALM over $32 \mathrm{~h}$ at $22^{\circ} \mathrm{C}$. We observed a significant $(P<0.05)$ increase in STEC on fresh-cut mango at $22^{\circ} \mathrm{C}(\Delta-\log 1.41 \log \mathrm{CFU} / \mathrm{g})$, whereas Strawn and Danyluk (41) did not observe sustained growth of this pathogen on fresh-cut mango held at $23^{\circ} \mathrm{C}$. Differences in strain selection and preparation or study design, and slight differences in incubation temperature, may account for variation in pathogen response between the two studies. Importantly, data presented by the two studies indicate the potential for STEC and SALM strains to survive and grow on cut mango under refrigeration $\left(\leq 5^{\circ} \mathrm{C}\right)$ and at room temperature $\left(22\right.$ to $\left.23^{\circ} \mathrm{C}\right)$, suggesting that if mango became contaminated during processing and was subsequently held, public health may be placed at risk. In addition, holding fresh-cut mango at 4 or $5^{\circ} \mathrm{C}$, although limiting growth of some pathogen strains, would not ensure safety because a documented log reduction in pathogens over time was not observed in either study.

Although holding fresh-cut onion at $5^{\circ} \mathrm{C}$ prevented statistically significant growth of SALM and STEC, more than 1-log growth of LM was observed (Table 3, $1.37 \mathrm{log}$ $\mathrm{CFU} / \mathrm{g}$ growth over $168 \mathrm{~h}$ ). This confirms the previous work of Neetoo et al. (34) wherein Salmonella and E. coli $\mathrm{O} 157: \mathrm{H} 7$ were unable to grow on green onion at $4^{\circ} \mathrm{C}$, but inocula survived for up to 14 days with no significant change in population. Placing fresh-cut onion at an abusive refrigeration temperature $\left(10^{\circ} \mathrm{C}\right)$ resulted in significant $(P$ $<0.05$ ) growth of SALM, STEC, and LM, with increases 
TABLE 3. Average pathogen growth rate and change in log of Salmonella (SALM), Shiga toxin-producing $E$. coll (STEC), and $L$. monocytogenes (LM) on fresh-cut onion, pepper, mango, cucumber, and tomato held at 5, 10, and $22^{\circ} \mathrm{C}(n=3)^{a}$

\begin{tabular}{|c|c|c|c|c|c|c|}
\hline \multirow[t]{2}{*}{$\begin{array}{l}\text { Storage temp for } \\
\text { produce item }\end{array}$} & \multicolumn{2}{|c|}{ SALM } & \multicolumn{2}{|c|}{ STEC } & \multicolumn{2}{|c|}{ LM } \\
\hline & $\mu^{b}$ & $\Delta-\log ^{c}$ & $\mu$ & $\Delta-\log$ & $\mu$ & $\Delta-\log$ \\
\hline \multicolumn{7}{|l|}{$5^{\circ} \mathrm{C}$} \\
\hline Onion & $0.00 \mathrm{a}$ & $0.25 \mathrm{aA}$ & $0.00 \mathrm{a}$ & $-0.19 a \mathrm{~A}$ & $0.02 \mathrm{a}$ & $1.37 \mathrm{aB}$ \\
\hline Pepper & $0.00 \mathrm{a}$ & $0.23 \mathrm{aA}$ & $0.00 \mathrm{a}$ & $0.02 \mathrm{aA}$ & $0.02 \mathrm{a}$ & $2.36 \mathrm{aB}$ \\
\hline Mango & $-0.01 \mathrm{a}$ & $-0.50 \mathrm{aA}$ & $0.00 \mathrm{a}$ & $-0.01 \mathrm{aA}$ & $0.00 \mathrm{a}$ & $-0.05 \mathrm{aA}$ \\
\hline Cucumber & $0.04 \mathrm{a}$ & $1.30 \mathrm{aA}$ & $0.02 \mathrm{a}$ & $0.39 \mathrm{aB}$ & $0.03 \mathrm{a}$ & $1.96 \mathrm{aA}$ \\
\hline Tomato & $0.00 \mathrm{a}$ & $0.27 \mathrm{aA}$ & $0.02 \mathrm{a}$ & $0.71 \mathrm{aA}$ & $0.00 \mathrm{a}$ & $-0.18 \mathrm{aB}$ \\
\hline \multicolumn{7}{|l|}{$10^{\circ} \mathrm{C}$} \\
\hline Onion & $0.11 \mathrm{~b}$ & $5.10 \mathrm{bA}$ & $0.08 \mathrm{~b}$ & $4.94 \mathrm{bA}$ & $0.04 \mathrm{~b}$ & $3.37 \mathrm{bB}$ \\
\hline Pepper & $0.09 \mathrm{~b}$ & $5.40 \mathrm{bA}$ & $0.09 \mathrm{~b}$ & $5.07 \mathrm{bA}$ & $0.08 \mathrm{~b}$ & $4.83 \mathrm{bA}$ \\
\hline Mango & $-0.01 \mathrm{a}$ & $0.00 \mathrm{aA}$ & $0.00 \mathrm{a}$ & $0.07 \mathrm{aA}$ & $0.00 \mathrm{a}$ & $0.01 \mathrm{aA}$ \\
\hline Cucumber & $0.08 \mathrm{a}$ & $5.24 \mathrm{bA}$ & $0.10 \mathrm{ab}$ & $5.25 \mathrm{bA}$ & $0.06 \mathrm{ab}$ & $4.19 \mathrm{bB}$ \\
\hline Tomato & $0.08 \mathrm{~b}$ & $4.36 \mathrm{bA}$ & $0.06 \mathrm{ab}$ & $2.87 \mathrm{abA}$ & $0.00 \mathrm{a}$ & $0.04 \mathrm{aB}$ \\
\hline \multicolumn{7}{|l|}{$22^{\circ} \mathrm{C}$} \\
\hline Onion & $1.10 \mathrm{c}$ & $4.63 \mathrm{bAB}$ & $0.88 \mathrm{c}$ & $4.98 \mathrm{bA}$ & $0.52 \mathrm{c}$ & $4.04 \mathrm{cB}$ \\
\hline Pepper & $0.80 \mathrm{c}$ & $5.66 \mathrm{bA}$ & $1.01 \mathrm{c}$ & $5.42 \mathrm{bA}$ & $0.55 \mathrm{c}$ & $4.77 \mathrm{bA}$ \\
\hline Mango & $0.15 \mathrm{a}$ & $2.85 \mathrm{bA}$ & $0.08 \mathrm{a}$ & $1.41 \mathrm{bAB}$ & $-0.05 \mathrm{a}$ & $-0.44 \mathrm{aB}$ \\
\hline Cucumber & $0.45 \mathrm{~b}$ & $5.28 \mathrm{bA}$ & $0.43 \mathrm{~b}$ & $5.27 \mathrm{bA}$ & $0.31 \mathrm{~b}$ & $4.64 \mathrm{bA}$ \\
\hline Tomato & $0.48 \mathrm{c}$ & $5.17 \mathrm{bA}$ & $0.31 \mathrm{~b}$ & $4.45 \mathrm{bA}$ & $0.06 \mathrm{a}$ & $0.54 \mathrm{aB}$ \\
\hline
\end{tabular}

${ }^{a}$ Values for pathogen growth rate $(\mu)$ are given in $\log \mathrm{CFU} / \mathrm{g} / \mathrm{h}$ and change in $\log (\Delta-\log )$ as CFU/g. Different lowercase letters appearing in a column indicate significant differences among growth rate or $\Delta$-log for a given pathogen-produce combination across different temperatures $(P<0.05)$. Different uppercase letters appearing in a row indicate significant differences among $\Delta$-log across pathogens for a given produce-temperature combination $(P<0.05)$.

${ }^{b} \mu$, growth rate $(\log \mathrm{CFU} / \mathrm{g} / \mathrm{h})$.

${ }^{c} \Delta$-log, change in $\log \mathrm{CFU} / \mathrm{g}$ time $_{\mathrm{x}}-$ time $_{0} ; \mathrm{x}=168 \mathrm{~h}$ at $5^{\circ} \mathrm{C}, 96 \mathrm{~h}$ at $10^{\circ} \mathrm{C}$, and $32 \mathrm{~h}$ at $22^{\circ} \mathrm{C}$.

\section{TABLE 4. Intrinsic characteristics of produce items used in this study}

\begin{tabular}{|c|c|c|c|}
\hline Produce item & $\operatorname{Avg} \mathrm{pH}^{a}$ & $a_{w}$ & Native microbiota $(\log \mathrm{CFU} / \mathrm{g})$ \\
\hline Cucumber & $5.67(5.46-5.88)^{b}$ & 0.998 & 2.93 \\
\hline Mango & $3.58(3.23-3.88)$ & 0.993 & 1.41 \\
\hline Onion & $5.47(5.39-5.64)$ & 0.994 & 1.21 \\
\hline Pepper & $5.60(5.42-5.77)$ & 0.994 & 2.24 \\
\hline Tomato & $4.44(4.32-4.56)$ & 0.993 & 1.24 \\
\hline
\end{tabular}

${ }^{a}$ Number of independent replicates $(n=x): \mathrm{pH}(3), \mathrm{a}_{\mathrm{w}}(1)$, average level of native microbiota at the start of each storage study (3).

${ }^{b}$ Range across three independent trials. 
of 5.10, 4.94, and $3.37 \log \mathrm{CFU} / \mathrm{g}$ over $96 \mathrm{~h}$, respectively. Elevating temperature to $22^{\circ} \mathrm{C}$ and holding for $32 \mathrm{~h}$ did not lead to a significant $(P>0.05)$ increase in SALM or STEC populations compared with $10^{\circ} \mathrm{C}$ but did allow for significant $(P<0.05)$ growth of LM (Table 3). Similarly, Neetoo et al. (34) observed population increases for E. coli O157:H7 and Salmonella of 3.8 to 4.7 and 3.6 to $4.6 \log \mathrm{CFU} / \mathrm{g}$, respectively, over an 8 -day incubation period at $22^{\circ} \mathrm{C}$. Others have observed growth of LM on diced onion under fluctuating temperature scenarios (27).

Pathogen response to temperature when inoculated onto fresh-cut pepper was similar to that of onion, with significant growth of $\mathrm{LM}$ at $5^{\circ} \mathrm{C}(2.36 \log \mathrm{CFU} / g$ growth over 168 $\mathrm{h})$, but not of SALM and STEC, and a dramatic increase in population across all pathogens at $10^{\circ} \mathrm{C}(\Delta-\log \mathrm{CFU} / \mathrm{g}$ of 5.40, 5.07, and 4.83 over $96 \mathrm{~h}$ for SALM, STEC, and LM, respectively) (Table 3). Growth of pathogens on fresh-cut pepper at $22^{\circ}$ was not significantly $(P>0.05)$ different from $10^{\circ} \mathrm{C}$. Castro-Rosas et al. (17) similarly noted growth of Salmonella and E. coli on sliced chili pepper at $25^{\circ} \mathrm{C}$, with growth of $\sim 4 \log$ CFU on pepper slices after $24 \mathrm{~h}$. Unlike our results, however, Castro-Rosas et al. (17) observed a 1 - to 2-log CFU reduction in population of Salmonella or E. coli strains on pepper slices after 6 days at $3^{\circ} \mathrm{C}$, presumably due to differences in either bacterial strains or incubation temperature, or perhaps due to antibacterial activity associated with sliced chilies (28). Castro-Rosas et al. (17) noted that survival of even a small number of Salmonella or other pathogens under refrigeration presents a serious health hazard to consumers due to the low infectious dose associated with many foodborne pathogens.

Holding of fresh-cut cucumber at $5^{\circ} \mathrm{C}$ allowed for significant growth of both SALM and LM $(\Delta-\log$ CFU/g of 1.30 and 1.96 , respectively) (Table 3 ). As seen with onion and pepper, increasing hold temperature to $10^{\circ} \mathrm{C}$ significantly $(P<0.05)$ increased pathogen growth over $5^{\circ} \mathrm{C}$. Holding inoculated fresh-cut cucumbers for $96 \mathrm{~h}$ at $10^{\circ} \mathrm{C}$ resulted in values of 5.24, 5.25, and 4.19 $\Delta-\log \mathrm{CFU} / \mathrm{g}$ for SALM, STEC, and LM, respectively. Whereas growth of SALM and STEC at $22^{\circ} \mathrm{C}$ was not significantly $(P>0.05)$ different from $10^{\circ} \mathrm{C}$, growth of LM was significantly higher at $22^{\circ} \mathrm{C}$ on fresh-cut cucumber (4.64 log CFU/g) over $32 \mathrm{~h}$ (Table 3). Bardsley et al. (7) found that LM populations significantly increased on sliced cucumbers $(2.9 \log \mathrm{CFU} / \mathrm{g})$ held at $4^{\circ} \mathrm{C}$, whereas Salmonella populations significantly decreased ( 1.3 $\log \mathrm{CFU} / \mathrm{g}$ ). The extended hold time in the Bardsley et al. (7) study (21 days) may account for the difference in results. Our results are, however, consistent with what others have observed for survival patterns of SALM and LM inoculated into cucumber tissue stored at $10^{\circ} \mathrm{C}(18), 23^{\circ} \mathrm{C}(7)$, or $25^{\circ} \mathrm{C}$ (22), but contrary to what has been observed for Salmonellainoculated cucumber slices stored $48 \mathrm{~h}$ at $4^{\circ} \mathrm{C}$, wherein no change in pathogen population was observed (22). The difference in study results can be explained by a difference in strain selection and study methodology. As with other produce items in this study, pathogen population numbers on chopped cucumber did not decrease on holding at $5^{\circ} \mathrm{C}$; instead; at least a doubling of inoculum population density was observed for SALM, STEC, and LM $(\Delta-\log >0.3 \log$ CFU/g) (Table 3). The ability of LM and SALM to grow on sliced cucumbers in short amounts of time at ambient temperatures (1 day) and to survive on sliced cucumbers past the recommended shelf life at refrigeration temperatures highlights the need to reduce the likelihood of contamination events throughout the cucumber supply chain (7).

Tomato is listed as a TCS food in the FDA Food Code and was included in this study as a positive control. Tomato tissue $\mathrm{pH}$ averaged 4.4 across trials. As expected, holding fresh-cut tomatoes for up to $196 \mathrm{~h}$ at $5^{\circ} \mathrm{C}$ did not allow for significant pathogen growth (Table 3 ). At an abusive refrigeration temperature $\left(10^{\circ} \mathrm{C}\right)$, there was significant $(P<$ 0.05 ) growth of SALM on fresh-cut tomato (4.36 log CFU/g over $96 \mathrm{~h}$ ) and a detectable increase in STEC that proved not significant $(P>0.05)$. At $22^{\circ} \mathrm{C}$, both SALM and STEC grew robustly on fresh-cut tomato $(\Delta-\log \mathrm{CFU} / \mathrm{g}$ of 5.17 and 4.45 , respectively) over $32 \mathrm{~h}$.

Beuchat et al. $(12,13)$ have investigated pathogen growth in tomato flesh. Acid-adapted and nonadapted strains of Salmonella were inoculated into 'Roma' tomato pulp $(\mathrm{pH} \sim 4.3)$ that was subsequently stored at 4,12 , and $21^{\circ} \mathrm{C}$. Salmonella populations increased $\sim 2 \log \mathrm{CFU} / \mathrm{g}$ over 10 days at $12^{\circ} \mathrm{C}$, but no population increase was observed at the first sampling point (3 days). A population increase of 3 to $4 \log \mathrm{CFU} / \mathrm{g}$ was noted by day 3 for tomato pulp stored at $21^{\circ} \mathrm{C}$, with little further change noted from day 3 to day 10. We observed greater increases in SALM populations inoculated onto fresh-cut tomatoes and held at 10 or $22^{\circ} \mathrm{C}$, likely due to differences in study methodology. Separate investigations into survival of E. coli O157: $\mathrm{H} 7$ inoculated into processed whole tomato (canned, peeled whole tomatoes, no other ingredients, $\mathrm{pH} 4.6$ ) did not show marked variation in pathogen count at $4^{\circ} \mathrm{C}$ over time. At $25^{\circ} \mathrm{C}$, however, the population of test strains increased by $\sim 3 \log \mathrm{CFU} / \mathrm{g}$ in the first $48 \mathrm{~h}$ (19), survival trends similar to what we observed.

Fresh-cut tomato did not support significant growth of LM at any holding temperature (Table 3). When Beuchat et al. (12) investigated survival of LM on chopped tomatoes held at 10 or $21^{\circ} \mathrm{C}$, they observed no population changes over the first 4 days of storage at $10^{\circ} \mathrm{C}$ and an $\sim 1-\log$ population decrease at $21^{\circ} \mathrm{C}$ over the first $48 \mathrm{~h}$. In the same study (12), when LM was inoculated into commercially processed tomato juice $(\mathrm{pH} 4.21)$, pathogen population did not change when held at $5^{\circ} \mathrm{C}$ for 7 days.

Holding fresh-cut produce for $196 \mathrm{~h}$ at $5^{\circ} \mathrm{C}$ failed to prevent significant $(P<0.05)$ growth of LM on onion, pepper, and cucumber $(\Delta-\log C F U / g$ of $1.37,2.36$, and 1.96, respectively). Significant growth of SALM on cucumber was also observed (Table 3, $1.30 \log \mathrm{CFU} / \mathrm{g}$ ). Overall, growth of pathogens on fresh-cut produce was not significantly different $(P<0.05)$ at 10 and $22^{\circ} \mathrm{C}$ for SALM and STEC 
inoculated onto onion, pepper, cucumber, and tomato (Table 3). Typical patterns observed for pathogens survival in freshcut produce held at $5^{\circ} \mathrm{C}$ are shown for SALM and LM in Fig. $1 a$ and $1 b$, respectively. Typical growth patterns of SALM at $10^{\circ} \mathrm{C}$ on fresh-cut produce are shown in Fig. 2.

Researchers $(26,50)$ have noted that incubation temperature and nutrient availability are major factors affecting pathogen growth and thus food safety risks associated with fresh-cut produce. The concept of timetemperature control for fresh produce, particularly freshcut fruits and vegetables, has historically been relied upon to maintain quality and extend the shelf life of whole produce and fresh-cut products $(31,44)$. The application of TCS as part of the FDA Food Code (43) is intended to prevent the growth of, or toxin formation by, pathogenic microorganisms. If time without temperature control is
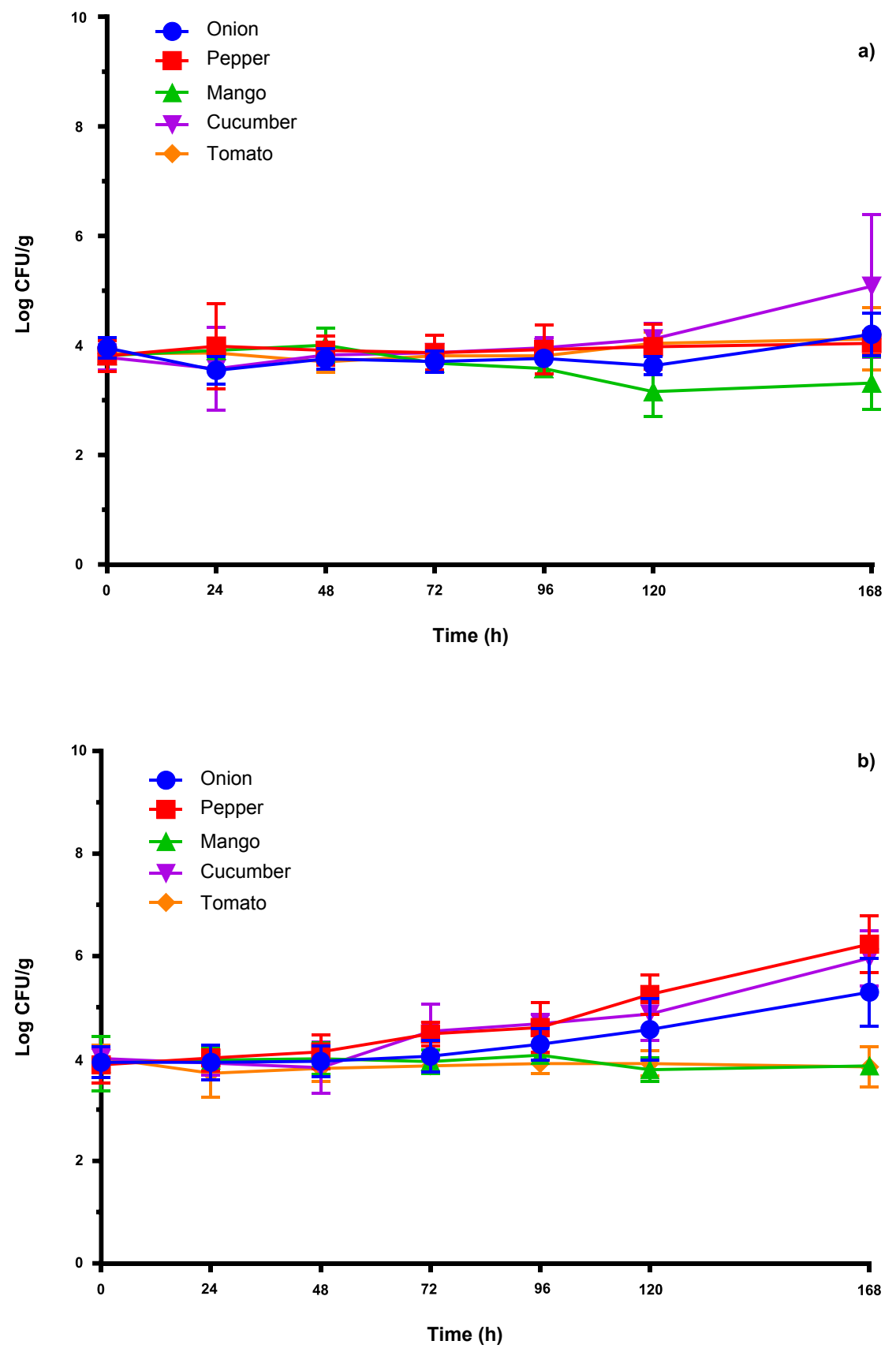

FIGURE 1. Behavior of pathogens (a) Salmonella spp. and (b) L. monocytogenes inoculated on fresh-cut produce items stored at $5^{\circ} \mathrm{C}$ for up to $168 \mathrm{~h}$. Bacterial populations (log CFU per gram) are the means of replicate trials $(n=3)$; error bars represent standard deviations. 


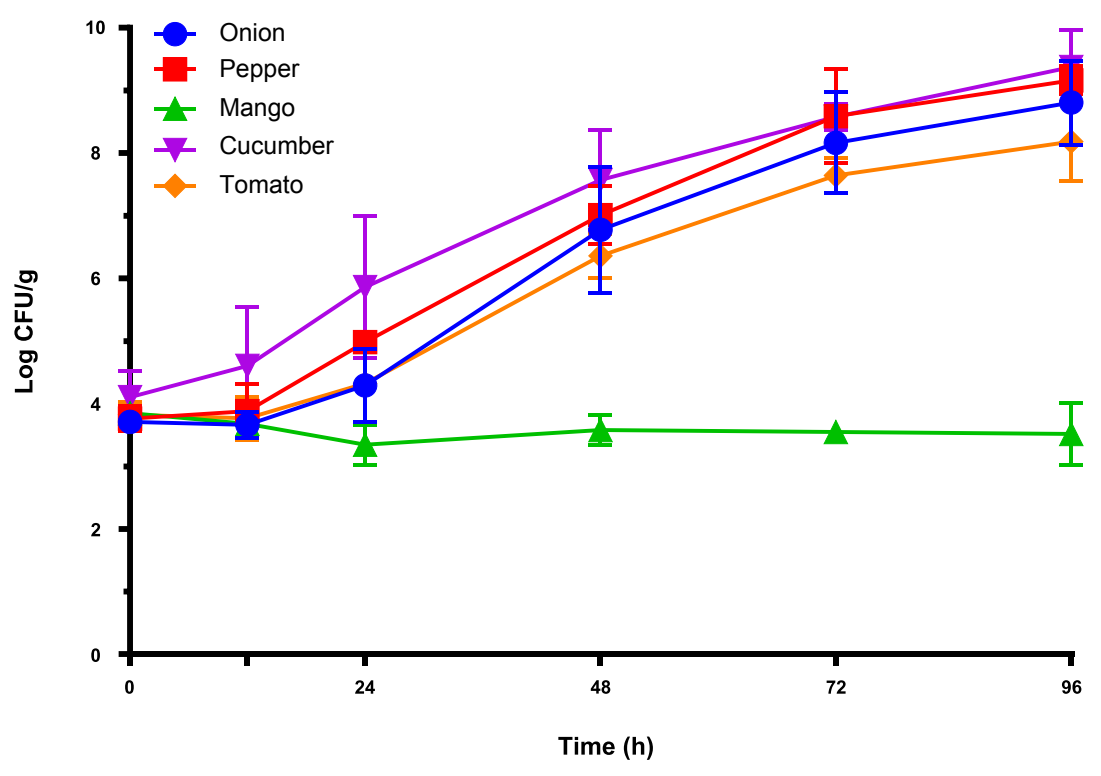

FIGURE 2. Behavior of Salmonella on fresh-cut produce items stored at $10^{\circ} \mathrm{C}$ for up to $96 \mathrm{~h}$. Bacterial populations $(\log \mathrm{CFU} / \mathrm{g})$ are the means of replicate trials $(n=3)$; error bars represent standard deviations.

used as the public health control, food that is displayed or held for sale or service may be held for a period of 4 to $6 \mathrm{~h}$, depending on ambient temperature, after which point the product must be cooked and served, consumed, or discarded. When food is prepared on-site at a retail establishment and held for more than $24 \mathrm{~h}$ on-site, the item must be clearly date marked and held at $\leq 5^{\circ} \mathrm{C}$ for no more than 7 days (43). A food item that is prepared and packaged by a food processing plant, and not a retail food establishment, may be held at the retail establishment, once opened, for a time not to exceed the manufacturer's use-by date based on food safety; holding at $\leq 5^{\circ} \mathrm{C}$ is required if the item is TCS. Our results suggest that on holding at $>5^{\circ} \mathrm{C}$, fresh-cut onion, pepper, mango, and cucumber all support growth of at least one pathogen that is reasonably likely to occur on the raw product. In addition to tomato that is already designated a TCS food, each of these fresh-cut items would reasonably be designated as a TCS food.

As McEntire (31) noted, good manufacturing practices under the Food Safety Modernization Act state, in part, in 21 CFR 117:

(b) Manufacturing operations. (2) All food manufacturing, including packaging and storage, shall be conducted under such conditions and controls as are necessary to minimize the potential for the growth of microorganisms, or for the contamination of food. One way to comply with this requirement is careful monitoring of physical factors such as time, temperature, humidity, $\mathrm{a}_{\mathrm{w}} \mathrm{pH}^{\mathrm{pH}}$, pressure, flow rate, and manufacturing operations such as freezing, dehydration, heat processing, acidification, and refrigeration to ensure that mechanical breakdowns, time delays, temperature fluctuations, and other factors do not contribute to the decomposition or contamination of food.
(3) Food that can support the rapid growth of undesirable microorganisms, particularly those of public health significance, shall be held in a manner that prevents the food from becoming adulterated within the meaning of the act. Compliance with this requirement may be accomplished by any effective means, including: (i) Maintaining refrigerated foods at $45^{\circ} \mathrm{F}\left(7.2^{\circ} \mathrm{C}\right)$ or below as appropriate for the particular food involved $(31,45)$.

McEntire (31) notes that essentially good manufacturing practices require the food industry to take measures to minimize the growth of pathogens in food. However, the food industry lacks information on which specific fresh fruits and vegetables support pathogen growth, thereby complicating the application of risk-based preventive controls such as time and temperature. And, given the broad number of intrinsic and extrinsic factors that affect pathogen growth on fresh-cut produce $(26,36)$, we would argue that application of appropriate food safety controls for fresh-cut produce can be complicated, especially at the consumer-retail interface. In some instances, the fresh-cut produce items that we studied supported pathogen growth even held under refrigeration $\left(5^{\circ} \mathrm{C}\right)$. Evaluating risk at the manufacturing level or at retail should include the consideration that fresh-cut produce may support the growth of pathogens, even when proper temperature controls are in place. Manufacturers and retailers intent on minimizing risk may need to consider additional interventions, i.e., heat or antimicrobial treatment, to protect public health.

Also notable in this study is that although pathogen growth was often not observed at $5^{\circ} \mathrm{C}$, temperature control did not result in any dramatic decrease in pathogen populations. The $\Delta$-log values at the end of incubation at $5^{\circ} \mathrm{C}$ ( 7 days) suggest 
that pathogens that find their way onto fresh-cut produce may survive during retail display and, in the likely absence of an intervention treatment applied by the consumer, could present a threat to public health. In the case of LM inoculated onto fresh-cut onion or pepper, or LM or SALM onto fresh-cut cucumber, there is the distinct possibility of an increased, not decreased, risk on holding at $5^{\circ} \mathrm{C}$ for up to the allowed 7 days. Were holding temperature to increase to $10^{\circ} \mathrm{C}$, at least episodically, or even the $7.2^{\circ} \mathrm{C}$ allowed under the Preventive Controls for Human Foods Rule (45), a situation not unlikely in retail display $(29,36)$, there is a heightened risk of pathogen presence on fresh-cut produce purchased by consumers. E. coli O157:H7 has been implicated in recent outbreaks of infections associated with fresh fruits and vegetables, and evidence suggests that holding temperature regimes normally thought to protect public health $\left(<7^{\circ} \mathrm{C}\right)$ are commonly exceeded during transport or retail display $(2,27,29,37)$.

Also noted in this study was the growth of SALM and STEC on mango on holding at $22^{\circ} \mathrm{C}$. Cut mango has a $\mathrm{pH}$ $<4.2$ and, as a non-TCS food, regulatory decision-making would support holding at $>5^{\circ} \mathrm{C}$ for extended periods, presumably without increasing risk. Our results, however, suggest that fresh-cut produce, including high-acid fruits, if contaminated and held at $>5^{\circ} \mathrm{C}$ could, in some instances, present a risk to public health.
Given the association between fruit and vegetable consumption and positive health outcomes $(33,42)$, the Dietary Guidelines for Americans encourage increased fruit and vegetable consumption across all age groups (42). At the same time, older adults, the very young, and the immune compromised are more likely to have some of the most severe complications from foodborne pathogen infections (15); therefore, these populations face heightened risk from consumption of contaminated fresh and fresh-cut produce. A recent report (6) of an investigation into a salmonellosis outbreak traced to fresh-cut fruits that sickened more than 150 people in 14 states noted that one of the factors likely contributing to the high hospitalization rate (66\% of confirmed cases) was the types of facilities that received the fruit, i.e., long-term care facilities, hospitals, and schools. For individuals in these vulnerable populations, any increase in pathogen population, or even the ability for existing pathogens to survive during retail holding or display, could present an unacceptable health risk. Certainly, our data support observations made by others that strategies aimed at reducing pathogen prevalence and concentration on produce growing in the field or orchard, or during processing and handling, are important in risk control $(7,37,41)$.

\section{REFERENCES}

1. Abadias, M., J. Usall, M. Anguera, C. Solsona, and I. Vinas. 2008. Microbiological quality of fresh, minimally-processed fruit and vegetables, and sprouts from retail establishments. Int. J. Food Microbiol.31:121-129.

2. Abdul-Raouf, U.M., L. R. Beuchat, and M. S. Ammar. 1993. Survival and growth of Escherichia coli O157:H7 on salad vegetables. Appl. Environ. Microbiol. 59:1999-2006.

3. Allen, K. J., J. Kovacevic, A. Cancarevic, J. Wood, J. Xu, B. Gill, J. Allen, and L. Mesak. 2013. Microbiological survey of imported produce available at retail across Canada. Int. J. Food Microbiol. 162:135-142.

4. Angelo, K. M., A. Chu, M. Anand, T.-A. Nguyen, L. Bottichio, M. Wise, I. Williams, S. Seelman, R. Bell, M. Fatica, S. Lance, D. Baldwin, K. Shannon, H. Lee, E. Trees, E. Strain, and L. Gieraltowski. 2015. Outbreak of Salmonella Newport infections linked to cucumbers - United States, 2014. Morb. Mortal. Wkly. Rep. 64:144-147.

5. Anonymous. Centers for Disease Control and Prevention. 2015. Multistate outbreak of Salmonella Poona infections linked to imported cucumbers. Available at: http://outbreakdatabase. com/ reports/2015_Salmonella_Poona_and cucumbers_10.14_.2015_.pdf. Accessed 15 October 2019.

6. Anonymous. Centers for Disease Control and Prevention. 2020. Outbreak of Salmonella infection linked to cut fruit. Available at: https://www.cdc.gov/salmonella/ javiana-12-19/index.html. Accessed 19 February 2020.

7. Bardsley, C. A., L. N. Truitt, R. C. Pfuntner, M. D. Danyluk, S. L. Rideout, and L. K. Strawn. 2019. Growth and survival of Listeria monocytogenes and Salmonella on whole and sliced cucumbers. J. Food Prot. 82:301-309.

8. Batz, M. B., S. Hoffman, and J. G. Morris, Jr. 2012. Ranking the disease burden of 14 pathogens in food sources in the United States using attribution data from outbreak investigations and expert elicitation. J. Food Prot. 75:1278-1291.

9. Beatty, M. E., T. N. LaPorte, Q. Phan, S. VanDuyne, and C. Braden. 2004. A multistate outbreak of Salmonella enterica serotype Saintpaul infections linked to mango consumption: a recurrent theme. Clin. Infect. Dis. 38:1337-1338.

10. Behravesh, C. B., D. Blaney, C. Medus, S. A. Bidol, Q. Phan, S. Soliva, E. R. Daly, K. Smith, B. G. Miller, T. Taylor, T. Nguyen, C. Perry, T. A. Hill, N. Fogg, A. Kleiza, D. Moorhead, S. Al-Khaldi, C. Braden, and M. F. Lynch. 2012. Multistate outbreak of Salmonella serotype Typhimurium infections associated with consumption of restaurant tomatoes, USA, 2006: hypothesis generation through case exposure in multiple restaurant clusters. Epidemiol. Infect. 140:2053-2061.

11. Bennett, S. D., K. W. Littrell, T. A. Hill, M. Mahovic, and C. B. Behravesh. 2014. Multistate foodborne disease outbreaks associated with raw tomatoes, United
States, 1990-2010: a recurring public health problem. Epidemiol. Infect. 143:1352-1359.

12. Beuchat, L. R., and R. E. Brackett. 1991. Behavior of Listeria monocytogenes inoculated onto raw tomatoes and processed tomato products. Appl. Environ. Microbiol. 57:1367-1371.

13. Beuchat, L. R., and D. A. Mann. 2008. Survival and growth of acid-adapted and unadapted Salmonella in and on raw tomatoes as affected by variety, stage of ripeness, and storage temperature. J. Food Prot. 71:1572-1579.

14. Bottichio, L., C. Medus, A. Sorenson, D. Donovan, R. Sharma, N. Dowell, I. Williams, A. Wellman, A. Jackson, B. Tolar, T. Griswold, and C. Basler. 2016. Outbreak of Salmonella Oslo infections linked to Persian cucumbers — United States, 2016. Morb. Mortal. Wkly. Rep. 65:1430-1433.

15. Buzby, J. C. 2002. Older adults at risk of complications from microbial foodborne illness. Food Rev. 25:30-35.

16. Callejón, R., R. Naranjo, M. Isabel, C. Ubeda, R. Hornedo-Ortega, M. Garcia-Parrilla, and A. Troncoso. 2015. Reported foodborne outbreaks due to fresh produce in the United States and European Union: trends and causes. Foodborne Pathog. Dis. 12:32-38.

17. Castro-Rosas, J., C. A. Gomez-Aldapa, O. A. Acevedo-Sandoval, C. A. Gonzalez Ramierez, J. R. Villagomez-Ibarra, N. C. Hernandez, A. Villarruel-Lopez, and M. delRefugio Torres-Vitela. 2011. Frequency and behavior of Salmonella and 
Escherichia coli on whole and sliced jalapeno and serrano peppers. J. Food Prot. 74:874-881.

18. Dhokane, V. S., S. Hajare, R. Shashidhar, A. Sharma, and J. R. Bandekar. 2006. Radiation processing to ensure safety of minimally processed carrot (Daucus carota) and cucumbe (Cucumis sativus): optimization of dose for the elimination of Salmonella Typhimurium and Listeria monocytogenes. J. Food Prot. 69:444-448.

19. Eribo, B., and M. Ashenafi. 2003. Behavior of Escherichia coli O157:H7 in tomato and processed tomato products. Food Res. Int. $36: 823-830$.

20. Fang, T., Y. Liu, and L. Huang. 2013. Growth kinetics of Listeria monocytogenes and spoilage microorganisms in fresh-cut cantaloupe. Food Microbiol. 34:174-181.

21. Francis, G. A., A. Gallone, G. J. Nychas, J. N. Sofos, G. Colelli, M. L. Amodio, and G. Spano. 2012. Factors affecting quality and safety of fresh-cut produce. Crit. Rev. Food Sci. Nutr. 52:595-610.

22. Guo, Y., M. Li, H. Han, and J. Cai. 2016. Salmonella enterica serovar Choleraesuis on fresh-cut cucumber slices after reduction treatments. Food Control 70:20-25.

23. Hanning, I. B., J. D. Nutt, and S. C. Ricke. 2009. Salmonellosis outbreaks in the United States due to fresh produce: sources and potential intervention measures. Foodborne Pathog. Dis. 6:635-648.

24. Harris, L. J., J. N. Farber, L. R. Beuchat, M. E. Parish, T. V. Suslow, E. H. Garrett, and F. F. Busta. 2003. Outbreaks associated with fresh produce: incidence, growth, and survival of pathogens in fresh and fresh-cut produce. Comp. Rev. Food Sci. Food Saf. 2:78-141.

25. Hassan, R., J. Rounds, A. Sorenson, G. Leos, J Conception-Acevendo, T. Griswold, A. Tesfai, T. Blessington, C. Hardy, and C. Basler. 2017. Multistate outbreak of Salmonella Anatum infections linked to imported hot peppers United States, May-July 2016. Morb. Mortal. Wkly. Rep. 66:663-667.

26. Huang, J., Y. Luo, B. Zhou, J. Zheng, and X. Nou. 2019. Growth and survival of Salmonella enterica and Listeria monocytogenes on fresh-cut produce and their juice extracts: impacts and interactions of food matrices and temperature abuse conditions. Food Control 100:300-304.

27. Jayeola, V., S. Jeong, E. Almenar, B. P. Marks, K. L. Vorst, J. W. Brown, and E. T. Ryser. 2019. Predicting the growth of Listeria monocytogenes and Salmonella Typhimurium in diced celery, onions, and tomatoes during simulated commercial transports, retail storage, and display. J. Food Prot. 82:287-300.

28. Koffi-Nevry, R., K. C. Kouassi, Z. Y. Nanga, M. Koussemon, and G. Y. Loukou. 2012. Antibacterial activity of two bell pepper extracts: Capsicum annuum L. and Capsicum frutescens. Int. J. Food Prop. 15:961-971. doi: https://doi.org/10.1080/10942912.2010. 509896.

29. Maistro, L. C., N. T. N. Miya, A. S. Sant'Ana, and J. L. Pereira. 2012. Microbiological quality and safety of minimally processed vegetables marketed in Campinas, SP - Brazil, as assessed by traditional and alternative methods. Food Control 28:258-264.

30. McCollum, J. T., A. B. Conquist, B. J. Silk, K. A. Jackson, K. A. O’Conner, S. Cosgrove, J. P. Gossack, S. S. Parachini, N. S. Jain, P. Ettestad, M. Ibraheem, V. Cantu, M. Jochi, T. DuVernoy, N. Fogg, J. R. Gorny, K. M. Mogen, C. Spires, P. Teitell, L. A. Joseph, C. L. Tarr, M. Imanishi, K. P. Neil, R. V. Tauxe, and B. E. Mahon. 2013. Multistate outbreak of listeriosis associated with cantaloupe. $N$. Engl. J. Med. 369:944-953.

31. McEntire, J. 2019. Time-temperature control for produce safety: tension between science and regulations. Food Prot. Trends 39:182-185.

32. Mody, R. K., S. A. Greene, L. Gaul, A. Sever, S. Pichette, I. Zambrana, T. Dang, A. Gass, R. Wood, K. Herman, L. B. Cantwell, G. Falkenhorst, K. Wannemuehler, R. M. Hoekstra, I. McCullum, A. Cone, L. Franklin, J. Austin, K. Delea, C. Barton Behravesh, S. V. Sodha, J. C. Yee, B. Emanuel, S. F. Al-Khaldi, V. Jefferson, I. T. Williams, P. M. Griffin, and D. L. Swerdlow. 2011. National outbreak of Salmonella serotype Saintpaul infections: importance of Texas restaurant investigations in implicating jalapeno peppers. PLoS One 6:e16579.

33. Moore, L. V., and F. E. Thompson. 2015. Adults meeting fruit and vegetable intake recommendations - United States, 2013 Morb. Mortal. Wkly. Rep. 64:709-713.

34. Neetoo, H., S. Nekoozadeh, Z. Jiang, and H. Chen. 2011. Application of high hydrostatic pressure to decontaminate green onions from Salmonella and Escherichia coli O157:H7. Food Microbiol. 28:1275-1283.

35. Rico, D., A. B. Martin-Diana, J. M. Barat and C. Barry-Ryan. 2007. Extending and measuring the quality of fresh-cut fruits and vegetables: a review. Trends Food Sci. Technol. 18:373-386.

36. Sant'Ana, A. S., M. S. Barbosa, M. T. Destro, M. Landgraf, and B. D. G. M. Franco. 2012. Growth potential of Salmonella spp. and Listeria monocytogenes in nine types of ready-to-eat vegetables stored at variable temperature conditions during shelf life. Int. J. Food Microbiol. 157:52-58.

37. Sant'Ana, A. S., B. D. G. M. Franco, and D. W. Schaffner. 2014. Risk of infection with Salmonella and Listeria monocytogenes due to consumption of ready-to-eat leafy vegetables in Brazil. Food Control 42:1-8.

38. Sant'Ana, A. S., M. C. Igarashi, M. Langraf, M. T. Destro, and B. D. G. Franco. 2012. Prevalence, populations and pheno- and genotypic characteristics of Listeria monocytogenes isolated from ready-to-eat vegetables marketed in São Paulo, Brazil. Int. J. Food Microbiol. 155:1-9.

39. Sant'Ana, A. S., M. Landgraf, M. T. Destro, and B. D. G. M. Franco. 2011. Prevalence and counts of Salmonella spp. in minimally processed vegetables in São Paulo, Brazil. Food Microbiol. 28:1235-1237.

40. Sivapalasingam, S., E. Barrett, A. Kimura, S. VanDuyne, W. DeWitt, M. Ying, A. Frisch,
Q. Phan, E. Gould, P. 1. Shillam, V. Reddy, T. Cooper, M. Hoekstra, C. Higgins, J. P. Sanders, R. V. Tauxe, and L. Slutsker. 2003. A multistate outbreak of Salmonella enterica serotype Newport infection linked to mango consumption: impact of water-dip disinfestation technology. Clin. Infect. Dis. 37:1585-1590.

41. Strawn, L. K., and M. D. Danyluk. 2010. Fate of Escherichia coli O157:H7 and Salmonella spp. on fresh and frozen cut mangoes and papayas. Int. J. Food Microbiol. 138:78-84.

42. U.S. Department of Agriculture, U.S. Department of Health and Human Services. 2020. Dietary Guidelines for Americans, 2015-2020, 8th ed. Available at: https:// health.gov/our-work/food-nutrition/2015 2020-dietary-guidelines/guidelines/. Accessed 3 January 2020

43. U.S. Food and Drug Administration. 2017. FDA Food Code. Available at: https:// www.fda.gov/food/fda-food-code/foodcode-2017. Accessed 15 October 2019.

44. U.S. Food and Drug Administration. 2018. Guidance for industry: guide to minimize microbial food safety hazards of fresh-cut fruits and vegetables. Available at: https:// www.fda.gov/regulatory-information/searchfda-guidance-documents/guidance-industryguide-minimize-microbial-food-safetyhazards-fresh-cut-fruits-and-vegetables. Accessed 15 October 2019

45. U.S. Food and Drug Administration. 2020. e-cfr Part 110.80. Available at: https://www.ecfr. gov/cgi-bin/text-idx?SID=ef15e8060d438565c fa6df4d 1 bceffd $5 \& \mathrm{mc}=$ true \&node $=$ se21.2.110 $180 \&$ rgn=div8. Accessed 3 January 2020.

46. Wadamori, Y., R. Gooneratne, and M. A. Hussain. 2017. Outbreaks and factors influencing microbiological contamination of fresh produce. J. Sci. Food Agric. 97:13961403. Available at: https://doi-org.ezproxy. library.wisc.edu/10.1002/jsfa.8125.

47. Walsh, K. A., S. D. Bennett, M. Hanovic, and L. H. Gould. 2014. Outbreaks associated with cantaloupe, watermelon, and honeydew in the United States, 1973-2011. Foodborne Pathog. Dis. 11:945-952.

48. Wheeler, C., T. M. Vogt, G. L. Armstrong, G. Vaughan, A. Weltman, O. V. Nainan, V. Dato, G. Xia, K. Waller, J. Amon, T. M. Lee, A. HighbaughBattle, C. Hembree, S. Evenson, M. A. Ruta, I. T. Williams, A. E. Fiore, and B. P. Bell. 2005. An outbreak of hepatitis A associated with green onions. N. Engl. J. Med. 353:890-897.

49. Zheng, W., K. Vorst, W. Brown, B. P. Marks, S. Jeong, F. Perez-Rodriguez, and E. Ryser. 2014. Growth of Escherichia coli O157:H7 and Listeria monocytogenes in packaged freshcut romaine mix at fluctuating temperatures during commercial transport, retail storage, and display. J. Food Prot. 77:197-206.

50. Ziegler, M., S. Ruegg, R. Stephan, and C. Guldimann. 2018. Growth potential of Listeria monocytogenes in six different RTE fruit products: impact of food matrix, storage temperature and shelf life. Ital. J. Food Saf. $7: 7581$. 